\title{
Detection of peste des petits ruminants virus in pneumonic lungs from apparently healthy sheep and goats slaughtered at Al-Hasaheisa slaughterhouse, Gezira state, central Sudan
}

\begin{tabular}{|c|c|}
\hline \multicolumn{2}{|c|}{ 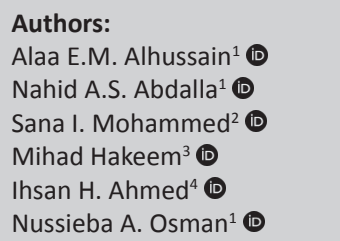 } \\
\hline $\begin{array}{l}\text { Affiliations: } \\
{ }^{1} \text { Department } 0 \\
\text { Parasitology ar } \\
\text { Microbiology, } \\
\text { Veterinary Me } \\
\text { University of S } \\
\text { Technology (SL } \\
\text { Khartoum-Nor }\end{array}$ & $\begin{array}{l}\text { f Pathology, } \\
\text { d } \\
\text { College of } \\
\text { dicine, Sudan } \\
\text { cience and } \\
\text { JST), } \\
\text { th, Sudan }\end{array}$ \\
\hline $\begin{array}{l}{ }^{2} \text { Virology Depa } \\
\text { Central Veteri } \\
\text { Laboratory (CV } \\
\text { Khartoum, Suc }\end{array}$ & $\begin{array}{l}\text { itment, } \\
\text { lary Research } \\
\text { (RL), Soba, } \\
\text { lan }\end{array}$ \\
\hline $\begin{array}{l}{ }^{3} \text { Epidemiology } \\
\text { Central Veteri } \\
\text { Laboratory (CV } \\
\text { Khartoum, Suc }\end{array}$ & $\begin{array}{l}\text { Department, } \\
\text { lary Research } \\
\text { (RL), Soba, } \\
\text { tan }\end{array}$ \\
\hline $\begin{array}{l}{ }^{4} \text { Viral Vaccine } \\
\text { Department, C } \\
\text { Veterinary Res } \\
\text { Laboratory (CV } \\
\text { Khartoum, Sud }\end{array}$ & $\begin{array}{l}\text { Production } \\
\text { entral } \\
\text { earch } \\
\text { (RL), Soba, } \\
\text { lan }\end{array}$ \\
\hline $\begin{array}{l}\text { Corresponding } \\
\text { Nussieba Osm } \\
\text { nussieba@yah }\end{array}$ & $\begin{array}{l}\text { author: } \\
\text { an, } \\
\text { oo.com }\end{array}$ \\
\hline $\begin{array}{l}\text { Dates: } \\
\text { Received: } 08 \mathrm{~J} \\
\text { Accepted: } 14 \mathrm{C} \\
\text { Published: } 17\end{array}$ & $\begin{array}{l}\text { uly } 2020 \\
\text { ct. } 2020 \\
\text { Dec. } 2020\end{array}$ \\
\hline Read online: & \\
\hline 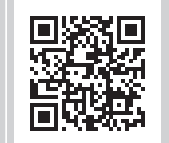 & $\begin{array}{l}\text { Scan this QR } \\
\text { code with your } \\
\text { smart phone or } \\
\text { mobile device } \\
\text { to read online. }\end{array}$ \\
\hline
\end{tabular}

The study aimed to investigate the presence of peste des petits ruminants (PPR) in pneumonic lung tissues from clinically apparently healthy sheep and goats and further demonstrating its prevalence in Gezira state, central Sudan. During March 2019, 99 pneumonic lung samples were collected from apparently healthy sheep (80) and goats (19) from Al-Hasaheisa slaughterhouse located in Al-Hasaheisa locality, Gezira state. Using the haemagglutination (HA) test for the detection of peste des petits ruminants virus (PPRV) antigen, an overall antigenic prevalence of $86.9 \%$ was demonstrated in sheep and goats lung tissue homogenate. Of note, the prevalence of PPRV is higher in goats $(100 \%)$ compared to sheep $(83.7 \%)$. In this study, the reported increasing prevalence of PPR in central Sudan might be because of insufficient vaccination of animals. The findings of the present study indicated the widespread of PPR amongst sheep and goats in Al-Hasaheisa, Gezira state. Detection of PPRV antigen in the pneumonic lung samples is an indication of exposure of these animals to PPRV or presence of PPR viral infection and demonstrates the role of PPR as the cause of pneumonia in small ruminants. In fact, the circulation of the virus in clinically apparently healthy animals poses a threat for other in-contact susceptible animals and could play a significant role in the spread of the disease.

Keywords: peste des petits ruminants; PPRV; Sudan; sheep; goats; pneumonic lungs; haemagglutination test.

\section{Introduction}

Peste des petits ruminants (PPR) is a highly contagious and fatal viral disease affecting domestic and wild small ruminants in developing countries (Edo, Deneke \& Abdela 2017; OIE 2019). Peste des petits ruminants virus (PPRV) causes high rates of deaths with morbidity and mortality rates ranging from $90 \%$ to $100 \%$ (Dhar et al. 2002; Singh \& Prasad 2008) amongst infected small animals, hence has a major economic effect in livestock, particularly in endemic areas, including the intertropical regions of Africa, the Arabian Peninsula, the Middle East and Asia (OIE 2019). Peste des petits ruminants virus also causes high rates of abortion in goats (Abubakar, Ali \& Khan 2008).

Peste des petits ruminants is caused by PPRV, classified in the Small Ruminant Morbillivirus $(S R M V)$ species, in the Morbillivirus genus, in the Paramyxoviridae family (Gibbs et al. 1979; Maes et al. 2019). Like other Morbillivirus members, PPRV is highly pathogenic for its natural hosts 'small ruminants' (Gibbs et al. 1979).

Peste des petits ruminants has been existing in Sudan since the first reported outbreak in 1971 in sheep and goats in three areas in Elgedarif (Elhag Ali 1973), which was at first diagnosed as rinderpest but later confirmed as PPR (Elhag Ali \& Taylor 1984). Peste des petits ruminants outbreaks were then reported in goats in Sinnar, central Sudan, during 1971-1972 and in Mieliq in 1972 (Elhag Ali \& Taylor 1984). Afterwards, PPR outbreaks were reported in Gezira state during 1990s (El Hassan et al. 1994). After the 2000s, outbreaks of PPR were reported in many parts of Sudan in sheep and goats (Osman 2005; Osman et al. 2018; Saeed et al. 2004, 2010, 2017), camels (Khalafalla et al. 2010; Kwiatek et al. 2011) and Dorcas gazelles (Asil et al. 2019), affecting the

How to cite this article: Alhussain, A.E.M., Abdalla, N.A.S., Mohammed, S.I., Hakeem, M., Ahmed, I.H. \& Osman, N.A., 2020, 'Detection of peste des petits ruminants virus in pneumonic lungs from apparently healthy sheep and goats slaughtered at Al-Hasaheisa slaughterhouse, Gezira state, central Sudan', Onderstepoort Journal of Veterinary Research 87(1), a1892. https://doi.org/10.4102/ojvr. v87i1.1892

Copyright: ( 2020. The Authors. Licensee: AOSIS. This work is licensed under the Creative Commons Attribution License. 
economy of the country. In recent years, PPR was demonstrated in lung samples collected from clinically healthy animals that showed lesions on post-mortem (PM) in slaughterhouses in Sudan (Saeed et al. 2017). Sheep, goats and cattle are the main sources of meat production in Sudan. Knowing that PPR is endemic causing significant losses amongst small ruminants, it is important to investigate its presence in the slaughtered animals. The present study aimed to investigate the presence of PPR and demonstrate the prevalence of PPRV antigen in pneumonic lung tissues from clinically apparently healthy sheep and goats slaughtered at Al-Hasaheisa slaughter house, Gezira state, central Sudan.

\section{Materials and methods}

\section{Study area}

The study was conducted in Al-Hasaheisa slaughterhouse located in Al-Hasaheisa locality, Gezira state (central Sudan) (Figure 1). Gezira state has an area of 27549 square kilometres $\left(\mathrm{km}^{2}\right)$ and is located between the coordinates $14^{\circ} 30^{\prime}$ North and $33^{\circ} 30^{\prime}$ East in central Sudan. Gezira state is composed of seven localities; however, the study was conducted only in Al-Hasaheisa locality in the western area of the state. Lung tissue samples were collected from Al-Hasaheisa abattoir, which is located at the margins of the town. Sheep, goats and cattle were slaughtered daily, except on Monday, in AlHasaheisa abattoir.

\section{Reference virus}

The live attenuated PPRV Nigeria $75 / 1$ vaccine strain was obtained as a freeze-dried preparation, dissolved into
0.5 millitres $(\mathrm{mL})$ of sterile distilled water, stored at $-20^{\circ} \mathrm{C}$ till used. The PPR vaccine was the positive control PPRV antigen used in the HA test and kindly provided by the Viral Vaccine Department, Central Veterinary Research Laboratory (CVRL), Soba, Khartoum.

\section{Sample collection and preparation}

During March to April 2019, a total of 99 lung samples with pneumonic lesions were collected from clinically apparently healthy sheep and goats, without considering its different sex, ages and breeds, from Al-Hasaheisa abattoir. These tissues were collected from sheep (80 samples) and goat (19 samples), preserved into sealed plastic bags, frozen at $-20{ }^{\circ} \mathrm{C}$.

A $20 \%(\mathrm{w} / \mathrm{v})$ tissue homogenate containing viral antigen was prepared from sheep and goats lung tissues in phosphate-buffer saline (PBS) ( $\mathrm{pH} 7.2-7.4)$ supplemented with antibiotics [1 $\mathrm{mL}$ of Penicillin (200 international units $[\mathrm{IU}] / \mathrm{mL}), 1 \mathrm{~mL}$ of Streptomycin (100 micrograms $[\mu \mathrm{g}] / \mathrm{mL}$ ), $1 \mathrm{~mL}$ of Gentamycin $(10000 \mu \mathrm{g} / \mathrm{mL})]$ and antifungal [0.5 mL of Fungizone (50 $000 \mathrm{IU} / \mathrm{mL})$ ] following the standard procedure. The homogenate was distributed into Eppendorf tubes and stored at $-20{ }^{\circ} \mathrm{C}$ and then used as antigen source for PPRV in the haemagglutination (HA) test.

\section{Preparation of red blood cells suspension}

Whole blood was collected, from healthy non-immunised chickens, in vacutainers containing anticoagulant 'Alsever's solution', red blood cells (RBCs) were washed three times

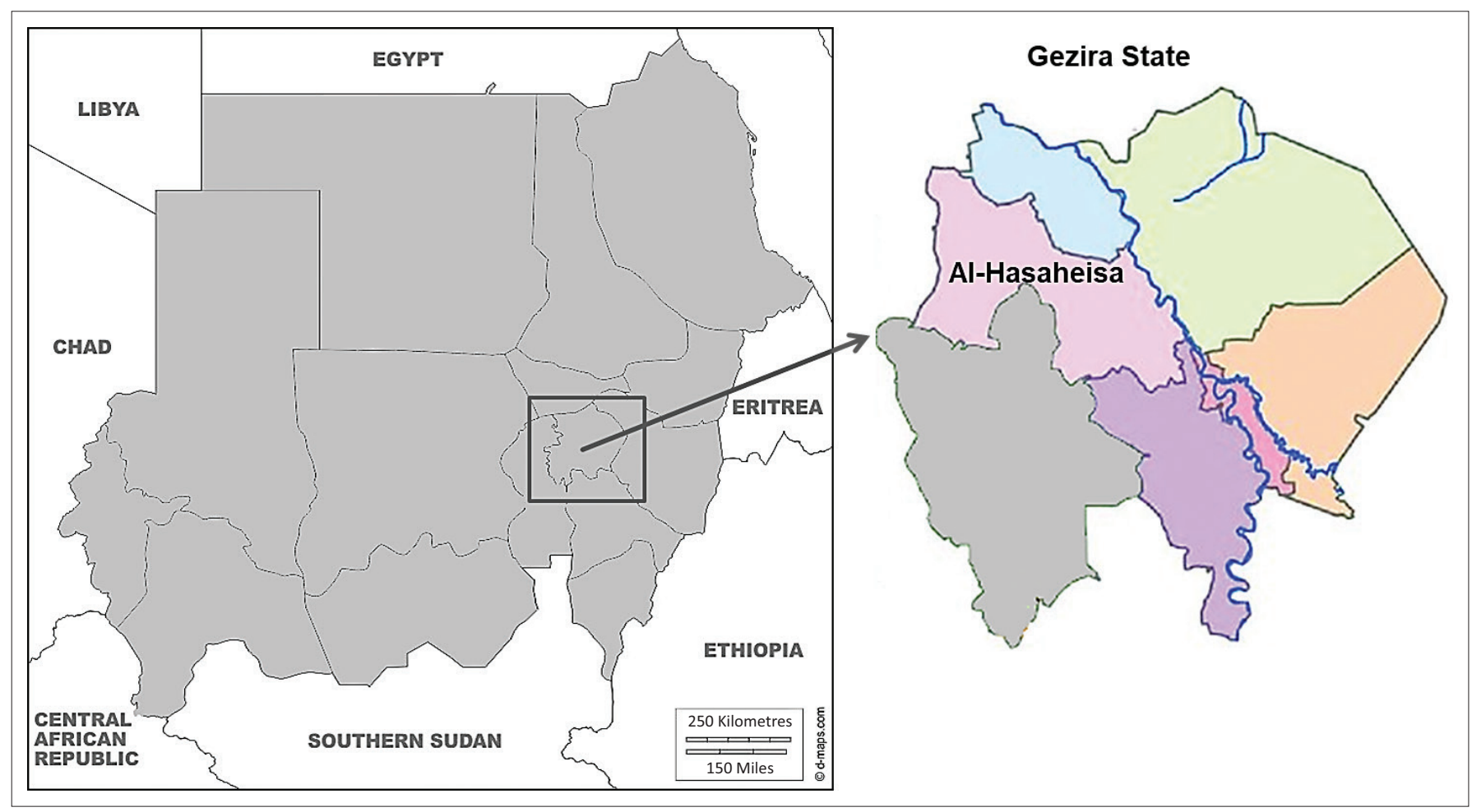

Source: Adapted from d-maps.com, n.d., Map of Sudan, available from http://www.d-maps.com/carte.php?num_car=1310\&lang=en

FIGURE 1: Map of Sudan showing the study area 'Al-Hasaheisa area in Gezira state, central Sudan'. 
and $0.8 \%$ of RBCs suspension was prepared in PBS (pH 6.8) following the standard procedure, the RBCs suspension was used as an indicator in the HA test.

\section{Haemagglutination test}

The HA test was used for identifying and quantifying PPRV antigen in the $20 \%$ tissue suspension of sheep and goats lung tissues following the procedure described previously by Ezeibe, Wosu and Erumaka (2004) and Osman (2005) with some modifications for the test conditions. To achieve highest HA titres, the HA test was performed in 96-well V-shaped bottom microtiter HA plates using PBS ( $\mathrm{pH}$ 6.8) as diluent, chicken RBCs suspension at $0.8 \%$ concentration, and the test plates were incubated in a refrigerator at $4{ }^{\circ} \mathrm{C}$ for $16-17 \mathrm{~min}$. Positive results were indicated by the formation of the HA sheet in the wells containing PPRV and negative results were indicated by the formation of the sharp red button of sediment RBCs at the bottom of the well. Red blood cells control appeared as a sharp red button (Figure 2). The end-point dilution for the haemagglutinating virus, which is equal to one HA unit (1 HAU), was determined as the last well that showed complete HA of RBCs. The haemagglutinationtitre (HA titre) of the virus in the sample was determined as the reciprocal of the end-point dilution and expressed as HAU.

\section{Ethical consideration}

This article followed all ethical standards for research without direct contact with human or live animal.

\section{Results}

To investigate the presence of PPR in sheep and goats pneumonic lungs from AL Hasaheisa slaughterhouse, the HA test for the detection of PPRV antigen was performed on $20 \%$ lung tissue homogenates prepared from the lung samples. The HA results took 16-17 min to appear, and the elution phenomenon happens rapidly at $18 \mathrm{~min}$ postincubation, where all positive HA results turned negative. With these optimised conditions (PBS with $\mathrm{pH}$ 6.8, using $\mathrm{V}$-shaped bottom HA plates and incubation at $4{ }^{\circ} \mathrm{C}$ ), the HA test could detect PPRV antigen.

Results of the HA test revealed that 86/99 lung samples were found positive, with an overall higher antigenic prevalence of $86.9 \%$, whilst $13(13.1 \%)$ samples were found negative. Moreover, the HA titres achieved ranged from 2 to $256 \mathrm{HAU}$, with a mean titre of 17 . Moreover, $2(2.0 \%)$ samples achieved the highest HA titre of $256 \mathrm{HAU}$ and 2 (2.0\%) samples achieved the highest HA titre of 128 HAU. Apparently, most of the samples $(29 / 99,29.3 \%)$ achieved a titre of $8 \mathrm{HAU}$ (Figure 3).

Considering the animals' species under study, in goats, all samples tested $(100 \%, 19 / 19)$ were found positive, whereas in sheep, of the 80 tested lung samples, $67(83.7 \%)$ proved positive, whereas $13(16.3 \%)$ lung samples proved negative

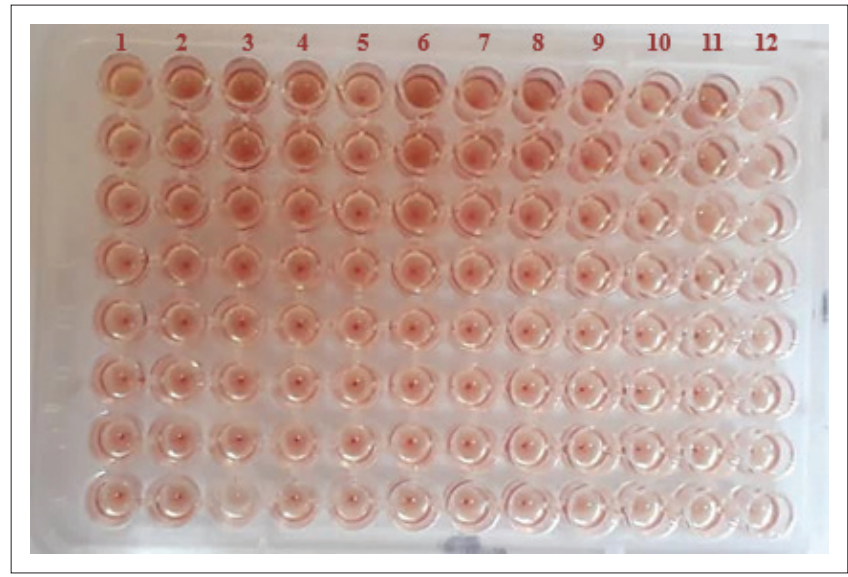

FIGURE 2: Haemagglutination test plate for detection of peste des petits ruminants virus antigen showing positive haemagglutination result as a diffused sheet or film and negative HA result as a sharp red button of sediment red blood cells. Peste des petits ruminants virus Control (Column 1), antigen samples (Columns 2-11), red blood cells control (Column 12). (Samples are in vertical position).

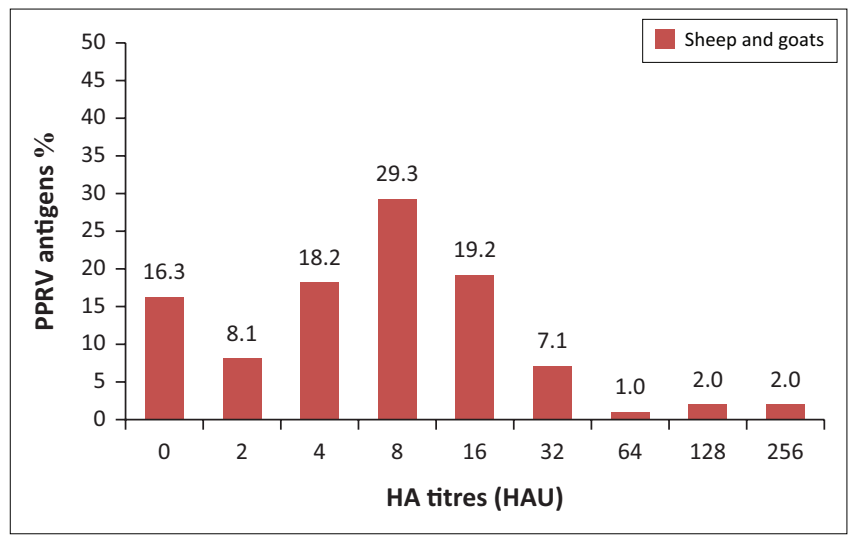

PPRV, peste des petits ruminants virus; HA, haemagglutination; HAU, haemagglutination unit.

FIGURE 3: Detection of PPRV in pneumonic lungs of both sheep and goat collected from Al-Hasaheisa slaughterhouse, Sudan. Distribution of haemagglutination titers.

(Figure 4). Amongst goats, HA results revealed that HA titres ranged from 2 to $256 \mathrm{HAU}$ with a mean titre of 22.7, one sample only (5.3\%) achieved the highest HA titre of 256 HAU, whereas most of the samples $(7 / 19,36.8 \%)$ achieved a titre of $4 \mathrm{HAU}$ (Figure 4). Amongst sheep, HA results similarly revealed that HA titres ranged from 2 to $256 \mathrm{HAU}$ with a mean titre of 15.6, one sample only (1.2\%) achieved the highest HA titre of $256 \mathrm{HAU}$ and 2 (2.5\%) samples achieved the highest HA titre of $128 \mathrm{HAU}$, whereas most of the samples $(25 / 67,31.3 \%)$ achieved a titre of 8 HAU (Figure 4$)$.

\section{Discussion}

This study was performed to investigate the presence of PPR and further demonstrate its prevalence in pneumonic lung samples from clinically apparently healthy sheep and goats slaughtered at Al-Hasaheisa slaughterhouse, Gezira state, central Sudan. Ninety-nine pneumonic lung samples from sheep (80) and goats (19) were screened using the HA test for detection of PPRV antigen. In this study, the HA test was used because of the demonstrated HA properties of PPRV as 


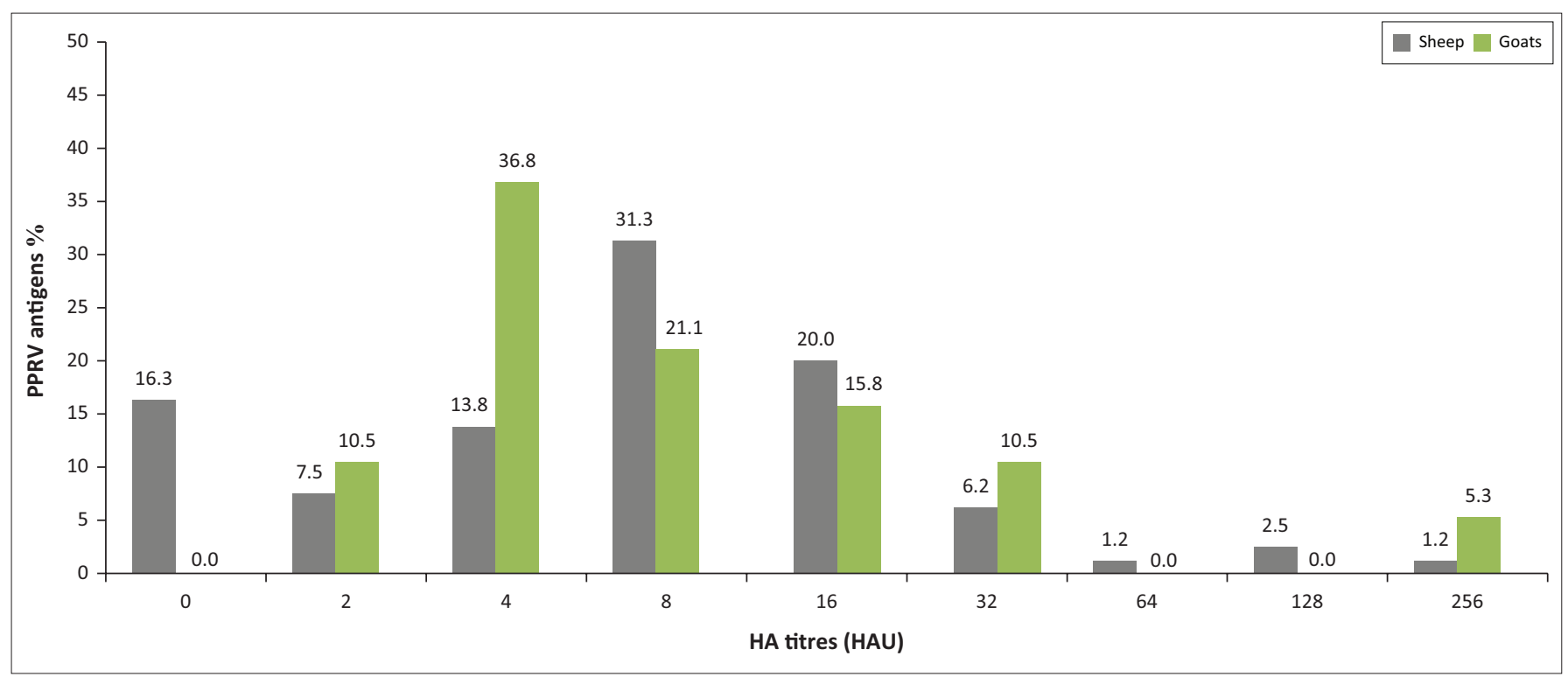

PPRV, peste des petits ruminants virus; HA, haemagglutination; HAU, haemagglutination unit.

FIGURE 4: Detection of PPRV in pneumonic lungs of sheep or goat collected from Al-Hasaheisa slaughterhouse, Sudan. Distribution of haemagglutination titers.

stated earlier (Ezeibe et al. 2004; Ramachandran et al. 1993; Wosu 1985, 1991). In a recent study by Rahman et al. (2020), the HA test was proved to be as sensitive as an immunocapture enzyme-linked immunosorbent assay (IC-ELISA) for detection of PPRV in nasal swabs and faecal samples from clinically PPR-suspected camels in Pakistan.

A 20\% lung tissue homogenates were prepared from sheep and goats pneumonic lung samples and used as an antigen in the HA test as performed earlier by Ezeibe et al. (2004) and Osman et al. (2008). Chicken RBCs were used in the HA test because it is the most sensitive RBCs for detection of PPRV antigen and it causes highest HA titers in a relatively short time as documented by Ezeibe et al. (2004) and Osman et al. (2008). Red blood cells suspension with $0.8 \%$ concentration in PBS ( $\mathrm{pH}$ 6.8) was used for obtaining the optimal result of the HA test for PPRV, according to Ezeibe et al. (2004). It is known that virus members of Paramyxoviridae and Orthomyxoviridae cause HA of RBCs and the results were obtained after using the normal conditions of the HA test (PBS with $\mathrm{pH} 7.4, \mathrm{U}$-shaped bottom HA plates and incubation at room temperature $20^{\circ} \mathrm{C}-25^{\circ} \mathrm{C}$ ). In this study, using these optimised conditions (PBS with $\mathrm{pH}$ 6.8, using V-shaped bottom HA plates and incubation at $4{ }^{\circ} \mathrm{C}$ ), the HA test could detect only PPRV but not other viruses.

Results of the HA test indicated $86 / 99$ positive samples with an overall higher antigenic prevalence of $86.9 \%$. This indicated the wide distribution of PPR in the central part of the country, which might be affected by the animal movement in these areas. Another study conducted during 2002-2004 in Sudan, using the HA test, revealed higher prevalence (92.5\%) amongst sheep and goats than that obtained in this study (Osman 2005; Osman et al. 2008). The prevalence of PPRV antigen obtained from Gezira state in this study is much higher compared to $54.3 \%$ prevalence in sheep and goats lung tissue samples, using IC-ELISA, reported recently in the central states of Sudan (Saeed et al. 2017). These results appear much higher compared to $15 \%$ antigenic prevalence demonstrated in pneumonic lung samples from sheep and goats, using reveres passive haemagglutination test (rPHA), in White Nile state in Sudan during 2008-2009 (Ishag, Saeed \& Ali 2015). Also it is much higher compared to $42.6 \%$ prevalence demonstrated in sheep tissue samples from PPR-suspected outbreaks in Sudan during 2008 using IC-ELISA (Saeed et al. 2010). In a recent study, lower prevalence $(18.3 \%$ ) of PPRV antigen was demonstrated in lung samples from different animal species using IC-ELISA (Saeed et al. 2017). In this study, the reported increasing prevalence of PPR is an indication of exposure of these animals to the virus and might be because of insufficient vaccination of animals.

Considering the species basis, all the goat samples (19/19 samples) were found positive with an overall prevalence of $100 \%$. The prevalence of PPRV antigen obtained from Gezira state in this study is much higher compared to $66.8 \%$ prevalence reported recently amongst goats in the central states of Sudan (Saeed et al. 2017). These results appear much higher to that described recently by Saeed et al. (2017), who reported a prevalence of $21.1 \%$ in lung samples from clinically apparently healthy goats in Sudan using ICELISA. In another study, a lower overall prevalence (63\%) of PPRV was demonstrated amongst goats in Eritrea by using an immunofluorescence test (Sumption et al. 1988). Another study performed on pneumonic lungs of goats in Bitlis and Van slaughterhouses, Turkey, revealed 40\% (17/42) prevalence of PPRV antigen amongst goats by using an immunohistochemical test (IHC) (Yener et al. 2004), which is much lower than the prevalence achieved in this study.

Considering the species basis, $67 / 80$ of the sheep samples were positive with an overall antigenic prevalence of $83.7 \%$. 
The prevalence of PPRV antigen obtained from Gezira state in this study is much higher compared to $70.7 \%$ prevalence reported recently amongst sheep in the central states of Sudan (Saeed et al. 2017). These results appear much higher to that described recently by Saeed et al. (2017), who reported a prevalence of $15.4 \%$ in lung samples from clinically apparently healthy sheep in Sudan using IC-ELISA. A much lower antigenic prevalence of $42.6 \%$ was demonstrated in sheep, using IC-ELISA, during 2008 in Sudan (Saeed et al. 2010). In the same study conducted in 2008, a lower overall prevalence of $27.3 \%$ was demonstrated amongst sheep in Gezira state using IC-ELISA (Saeed et al. 2010).

The findings indicated the presence and the higher prevalence of PPR amongst sheep and goat populations in Al-Hasaheisa Gezira state, Sudan, considering that these lung samples were collected from clinically apparently healthy animals. Detection of PPRV antigen in the pneumonic lung samples is an indication of exposure of these animals to PPRV or PPR viral infection and demonstrates the role of PPR as the cause of pneumonia in small ruminants. In fact, the circulation of the virus in clinically apparently healthy animals, that might excrete the virus in the environment, poses a threat for other in-contact susceptible animals and could play a significant role in the spread of the disease. Results of the study demonstrated the widespread of the disease not only in AlHasaheisa town but also in its neighbouring villages because most of these animals found in Al-Hasaheisa were brought from the neighbouring villages. The higher prevalence achieved indicated the potential exposure of these animals to PPRV and the wide distribution of the disease amongst small ruminants in central Sudan, which is considered as PPR endemic areas. For control and rapid elimination of the disease, local authorities should increase the awareness of small ruminant owners, regarding the economic problem and losses caused by the disease and the importance of animal vaccination against the disease.

\section{Acknowledgements}

The authors would like to thank Dr Mohammed Hayati, AlHasaheisa slaughterhouse, Gezira state, for his help in sample collection to the staff of the departments of Virology, Molecular Biology and the Viral Vaccine Production, the Central Veterinary Research Laboratory, Soba and Sudan University of Science and Technology (SUST), for assistance with the laboratory experiment.

\section{Competing interests}

The authors have declared that no competing interests exist.

\section{Authors' contributions}

A.E.M.A. performed sample collection and preparation, laboratory work, data analysis and results interpretation, and prepared the drafted manuscript.

N.A.S.A., S.I.M., M.H. and I.H.A. helped with the laboratory work.
N.A.O. designed and supervised the research work, performed laboratory work, data analysis and results interpretation, prepared and finalised the manuscript.

\section{Funding information}

The research in this study was funded by a research project for Nussieba A. Osman from the Republic of the Sudan, Sudanese Ministry of Higher Education and Scientific Research, Commission of Scientific Research and Innovation (Grant No. 2017/972).

\section{Data availability statement}

Data sharing is not applicable to this article as no new data were created or analysed in this study.

\section{Disclaimer}

The views and opinions expressed in this article are those of the authors and do not necessarily reflect the official policy or position of any affiliated agency of the authors.

\section{References}

Abubakar, M., Ali, Q. \& Khan, H.A., 2008, 'Prevalence and mortality rate of peste des petits ruminant (PPR): Possible association with abortion in goat', Tropical Animal Health and Production 40(5), 317-321. https://doi.org/10.1007/s11250-0079105-2

Asil, R.M., Ludlow, M., Ballal, A., Alsarraj, S., Ali, W.H., Mohamed, B.A. et al., 2019, 'First detection and genetic characterization of peste des petits ruminants virus from Dorcas gazelles "Gazella dorcas" in the Sudan, 2016-2017', virus from Dorcas gazelles "Gazella dorcas" in the Sudan, 2016-2017',
Archives of Virology 164(10), 2537-2543. https://doi.org/10.1007/s00705-019Archives of
$04330-w$

Dhar, P., Sreenivasa, B.P., Barrett, T., Corteyn, M., Singh, R.P. \& Bandyopadhyay, S.K., 2002, 'Recent epidemiology of peste des petits ruminants virus (PPRV)', Veterinary Microbiology 88(2), 153-159. https://doi.org/10.1016/S0378-1135(02) 00102-5

d-maps.com, n.d., Map of Sudan, available from http://www.d-maps.com/carte. php?num_car=1310\&lang=en

Edo, T., Deneke, Y. \& Abdela, N., 2017, 'Peste des petits ruminants and its economic importance', Global Veterinaria 18(4), 256-268.

El Hassan, A.K.M., Ali, Y.O., Hajir, B.S., Fayza, A.O. \& Hadia, J.A., 1994, 'Observation on the epidemiology of peste des petits ruminants in the Sudan', The Sudan Journa of Veterinary Research 13, 29-34.

Elhag Ali, B., 1973, 'A natural outbreak of rinderpest involving sheep, goats and cattle in Sudan', Bulletin of Epizootic Diseases of Africa 21(4), 421-428.

Elhag Ali, B. \& Taylor, W.P., 1984, 'Isolation of peste des petits ruminants virus from the Sudan', Research in Veterinary Science 36(1), 1-4. https://doi.org/10.1016/S00345288(18)31991-X

Ezeibe, M.C.O., Wosu, L.O. \& Erumaka, I.G., 2004, 'Standardisation of the haemagglutination test for peste des petits ruminants (PPR)', Small Ruminant Research 51(3), 269-272. https://doi.org/10.1016/S0921-4488(03)00123-8

Gibbs, E.P.J., Taylor, W.P., Lawman, M.J.P. \& Bryant, J., 1979, 'Classification of peste des petits ruminants virus as the fourth member of the genus morbillivirus', Intervirology 11(5), 268-274. https://doi.org/10.1159/000149044

Ishag, O.M., Saeed, I.K. \& Ali, Y.H., 2015, 'Peste des petits ruminants outbreaks in White Nile State, Sudan', Onderstepoort Journal of Veterinary Research 82(1), 1-4. https://doi.org/10.4102/ojvr.v82i1.897

Khalafalla, A.I., Saeed, I.K., Ali, Y.H., Abdurrahman, M.B., Kwiatek, O., Libeau, G. et al., 2010, 'An outbreak of peste des petits ruminants (PPR) in camels in the Sudan', Acta Tropica 116(2), 161-165. https://doi.org/10.1016/j.actatropica.2010. Acta Trop
08.002

Kwiatek, O., Ali, Y.H., Saeed, I.K., Khalafalla, A.I., Mohamed, O.I., Obeida, A.A. et al., 2011, 'Asian lineage of peste des petits ruminants virus, Africa', Emerging Infectious Diseases 17(7), 1223-1231. https://doi.org/10.3201/eid1707.101216

Maes, P., Amarasinghe, G.K., Ayllón, M.A., Basler, C.F., Bavari, S., Blasdell, K.R. et al., 2019, 'Taxonomy of the order Mononegavirales: Second update', Archives of Virology 164(4), 1233-1244. https://doi.org/10.1007/s00705-018-04126-4

OIE, 2019, 'Peste des petits ruminants (Infection with peste des petits ruminants virus)', in Manual of diagnostic tests and vaccines for terrestrial animals, 7th edn. Chapter 3.7.9, Office International des Epizooties (OIE), Paris, available from https://www.oie.int/standard-setting/terrestrial-manual/access-online/ 
Osman, N.A., 2005, 'Peste des petits ruminants in Sudan: Detection, virus isolation and indentification, pathogenicity and serosurveillance', Thesis for master degree, University of Khartoum, Sudan.

Osman, N.A., A/Rahman, M.E., Ali, A.S. \& Fadol, M.A., 2008, 'Rapid detection of peste des petits ruminants (PPR) virus antigen in Sudan by agar gel precipitation (AGPT)
and haemagglutination (HA) tests', Tropical Animal Health and Production 40(5), 363-368. https://doi.org/10.1007/s11250-007-9106-1

Osman, N.A., Ibrahim, H.M.A., Osman, A.A., Alnour, R.M. \& Gamal Eldin, O.A., 2018 'Sero-prevalence of peste des petits ruminants virus antibodies in sheep and goats from the Sudan, 2016-2017', Virus Disease 29(4), 531-536. https://doi. goats from the Sudan, 2016-2017
org/10.1007/s13337-018-0496-7

Rahman, H., Kamboh, A.A., Abro, S.H. \& Abubakar, M., 2020, 'An investigation on the prevalence of peste des petits ruminants in the camels of Sindh, Pakistan', Tropical Animal Health and Production 52(4), 1863-1867. https://doi.org/10.1007/ Animal Health and

Ramachandran, S., Hedge, N.R., Raghavan, R., Subbarao, M.S. \& Shyam, G., 1993 'Haemagglutination by PPR virus', in Proceedings of The 3rd International Sheep Veterinary Conference, Edinburgh, pp. 1-2.

Saeed, I.K., Ali, Y.H., Haj, M.A., Sahar, M.A.T., Shaza, M.M., Baraa, A.M. et al., 2017, 'Peste des petits ruminants infection in domestic ruminants in Sudan', Tropical Animal Health and Production 49(4), 747-754. https://doi.org/10.1007/s11250017-1254-3
Saeed, I.K., Khalafalla, A.I., El Hassan, S.M. \& El Amin, M.A., 2004, 'Peste des petits ruminants (PPR) in the Sudan: Investigation of recent outbreaks, virus isolation and cell culture spectrum', Journal of Animal and Veterinary Advances (JAVA) 3(6), and cell cultu.

Saeed, I.K., Yahia, H.A., Abdalmelik, I.K. \& Mahasin, E.A., 2010, 'Current situation of peste des petits ruminants (PPR) in Sudan', Tropical Animal Health and Production 42(1), 89-93. https://doi.org/10.1007/s11250-009-9389-5

Singh, B. \& Prasad, S., 2008, 'Modelling of economic losses due to some important diseases in goats in India', Agricultural Economics Research Review 21(2), 297-302.

Sumption, K.J., Aradom, G., Libeau, G. \& Wilsmore, A.J., 1998, 'Detection of peste des petits ruminants virus antigen in conjunctival smears of goats by indirect immunofluorescence', Veterinary Record 142(16), 421-424. https://doi. org/10.1136/vr.142.16.421

Wosu, L.O., 1985, 'Agglutination of red blood cells by peste des petits ruminants (PPR) virus', Nigerian Veterinary Journal 14, 56-58.

Wosu, L.O., 1991, 'Haemagglutination test for diagnosis of peste des petits ruminants disease in goats with samples from live animals', Small Ruminant Research 5(1-2), 169-172. https://doi.org/10.1016/0921-4488(91)90041-N

Yener, Z., Sa glam, Y.S., Temur, A. \& Keles, H., 2004, 'Immunohistochemical detection of peste des petits ruminants viral antigens in tissues from cases of naturally
occurring pneumonia in goats', Small Ruminant Research 51(3), 273-277. https:// occurring pneumonia in goats', Small Ruming 